http://dx.doi.org/10.18778/8088-329-1.05

Jadwiga Zapala, Marzena Pyk, Miroslawa Tekiel

ŚWIĘTOKRZYSKIE CenTRuM ONKOLOGII

BożENA ZAWADZKA

UnIWERSYTET JaNa KOCHANOWSKIEGO W KIELCACH

\title{
Strategie w edukacji onkologicznej młodzieży w szkołach województwa świętokrzyskiego
}

\section{The strategies in oncology education of youth in schools of Swietokrzyskie Voivodeship}

Since the 80 s of the last century, the epidemiological studies have helped scientists to recognize that the significant proportion of all cancers is caused by a defective way of life, and above all smoking, irregular diet and lack of physical activity. Therefore one of the strategies that was adopted for cancer prevention were the pro-health education activities, the implementation of which have been formulated in the European Code Against Cancer.

Since 2006, Holycross Cancer Center has conducted educational activities for society on the recommendations of the European Code Against Cancer as part of the Primary Cancer Prevention tasks due to the National Programme for Combating Cancer in the years 2006-2015. These actions are aimed particularly at children and young people, as well as teachers and educators. At the same time, there are many actions referred to health professionals and the general public, including conferences, educational meetings, preventive actions and media campaigns.

In 2010-2012, nearly 3,000 schools from Małopolskie Voivodeship and Podkarpackie Voivodeship have implemented a pilot program named "School Promoting the recommendations of the European Code Against Cancer", which contains various forms of education towards young people to acquaint them with the recommendations of the Code. In the years 2013-2015 the project was implemented in Świętokrzyskie Voivodeship by Holycross Cancer Center. In 2013/2014 school year, there were 146 schools participating in the project, while in the next school year it was attended by 
234 schools, which proves the great interest in the project and the need to implement actions in the field of oncology education in schools. During that time, 20457 students were acquainted with the recommendations of the European Code Against Cancer, 6333 from 66 primary schools, 8045 from 48 middle schools and 6079 from 32 high schools. During the next school year (2014/2015) the project involved slightly less students (18 810), 6555 from 104 primary schools, 8352 from 82 middle schools and 3903 from 48 high schools.

The participants engaged in the project, asked about their opinion, confirmed that they would be happy to take part in the program again, because of the importance of the topic and the need to increase public awareness of cancer prevention among children and parents.

\section{Wprowadzenie}

Nowotwory złośliwe są jednym z istotniejszych problemów zdrowotnych społeczeństw XXI wieku. Co roku rozpoznawane są na świecie u blisko $11 \mathrm{mln}$ osób, a prawie $7 \mathrm{mln}$ ludzi umiera rocznie $z$ ich powodu. $Z$ rozpoznaniem nowotworu złośliwego żyje obecnie blisko $25 \mathrm{mln}$ osób. Prognozy wskazują, że do 2020 roku liczba rocznych zachorowań wzrośnie do $16 \mathrm{mln}$ ludzi na całym świecie, a liczba zgonów do $10 \mathrm{mln}$ rocznie. Szacuje się przy tym, że aż 70\% zgonów nowotworowych wystąpi w krajach rozwijających się, które charakteryzuje mała aktywność w działaniach na rzecz walki z rakiem (Światowa deklaracja walki z rakiem, 2006).

Środowiska medyczne i organizacje walki z rakiem z całego świata nieustannie apelują o zintensyfikowanie działań z zakresu prewencji nowotworów we wszystkich krajach. Już w 2000 roku podczas Światowego szczytu walki z rakiem powstała Paryska karta walki rakiem, w której poza postulatami dotyczącymi rozwoju onkologii i zwiększenia nakładów finansowych na badania naukowe uwzględnione zostało wdrożenie promocji zdrowia jako formy zapobiegania nowotworom (Paryska karta walki z rakiem, 2015). W 2006 roku podczas Światowego kongresu onkologicznego w Waszyngtonie uszczegółowiono zalecenia z karty paryskiej, wzywając między innymi do uwzględnienia w narodowych programach przeciwnowotworowych nie tylko wydatków na leczenie i opiekę paliatywną, ale również prewencję pierwotną, ze szczególnym zwróceniem uwagi na zwalczanie palenia tytoniu (Światowa deklaracja walki z rakiem, 2006).

\section{Prewencja pierwotna nowotworów złośliwych w oparciu o zalecenia Europejskiego kodeksu walki z rakiem}

Już od lat osiemdziesiątych ubiegłego wieku liczne badania epidemiologiczne podkreślały rolę wadliwego stylu życia w zwiększaniu ryzyka nowotworów złośliwych, w tym szczególnie: palenia tytoniu, nieracjonalnego odżywiania oraz braku aktywności ruchowej, prowadzących dodatkowo do nadwagi i otyłości. Tym samym też edukacja społeczeństwa w zakresie prozdrowotnego stylu życia stała się ważnym elementem strategii zapobiegania nowotworom, a zasady konieczne do jego wdrożenia sformułowano w tzw. Europejskim kodeksie walki z rakiem. 
Tabela 1. Czynniki środowiskowe a zgony na nowotwory złośliwe

\begin{tabular}{|l|c|}
\hline \multicolumn{2}{|c|}{ Czynniki środowiskowe a zgony na nowotwory złośliwe } \\
\hline \multicolumn{1}{|c|}{ Czynnik środowiskowy } & Procent zgonów \\
\hline Dieta & 35 \\
\hline Tytoń & 30 \\
\hline Czynniki seksualne i prokreacyjne & 7 \\
\hline Alkohol & 5 \\
\hline Czynniki zawodowe & 4 \\
\hline Czynniki geograficzne & 3 \\
\hline Skażenie środowiska & 2 \\
\hline Produkty przemysłowe & 1 \\
\hline Dodatki do żywności & 1 \\
\hline Leki & 1 \\
\hline Inne & 11 \\
\hline
\end{tabular}

Źródło: IARC, 2001, za: Jarosz, 2008.

Pierwsza wersja kodeksu opracowana została już w 1987 roku przez Komitet Ekspertów Wysokiego Szczebla przy Komisji Europejskiej. W 2003 roku ukazała się trzecia wersja kodeksu, uwzględniająca zarówno zalecenia dla ogółu społeczeństwa dotyczące modyfikacji pewnych elementów stylu życia (unikanie palenia tytoniu, otyłości, codzienna aktywność ruchowa, większa ilość warzyw i owoców a ograniczenie tłuszczów zwierzęcych w diecie, ochrona przed promieniowaniem słonecznym) oraz stosowania szczepień przeciwko wirusowemu zapaleniu wątroby, jak również wskazówki dla wybranych grup odbiorców odnośnie do uczestnictwa w programach badań, pozwalających zwiększyć wykrywalność nowotworów we wczesnej fazie (Zatoński, 2009).

Czwarta już edycja tego dokumentu została ogłoszona 14 października 2014 roku. Zawarte w niej zalecenia zamieszczono na stronie internetowej koordynatora projektu poświęconej pracom nad przygotowaniem kodeksu - Międzynarodowej Agencji Badań nad Rakiem (Międzynarodowa Agencja Badań nad Rakiem [IARC], 2015).

Obecna wersja kodeksu składa się z dwunastu zaleceń. Aż dwa z nich poświęcono paleniu tytoniu, które stanowi jedną z najważniejszych przyczyn zachorowań nowotworowych. Jeszcze mocniej niż w poprzedniej wersji zaakcentowano potrzebę ochrony osób niepalących, zalecając utrzymywanie domu wolnego od tytoniu (IARC, 2015).

Rozszerzono także zakres diety korzystnej dla profilaktyki raka, dodając do niezbędnych w menu warzyw i owoców także produkty pełnoziarniste. Zaproponowano również w oparciu o wyniki badań ograniczenie nie tylko tłuszczów, przetworzonego i czerwonego mięsa, ale również pokarmów wysokokalorycznych i soli. Zaostrzono zalecenie dotyczące spożycia alkoholu, sugerując całkowite jego wyłączenie z diety (IARC, 2015).

Kolejny raz podkreślono rolę codziennej aktywności fizycznej w ograniczaniu ryzyka wielu nowotworów, przestrzegając jednocześnie przed skutkami zdrowotnymi siedzącego trybu życia (IARC, 2015). 
W stosunku do trzeciej edycji poszerzono również zalecenia dotyczące prewencji nowotworów skóry o konieczność unikania korzystania z solariów, jako najważniejszego, udowodnionego badaniami czynnika nowotworów skóry, szczególnie u młodych osób (IARC, 2015).

W czwartej wersji kodeksu pojawiły się także zalecenia dotyczące ochrony przed znanymi już substancjami rakotwórczymi oraz promieniowaniem radonowym, którego wysokie stężenie w pomieszczeniach również jest czynnikiem ryzyka nowotworów (IARC, 2015).

Zwrócono uwagę na popularną dziś wśród kobiet w wieku okołomenopauzalnym hormonalną terapię zastępczą, jako czynnik ryzyka raka piersi, oraz pozytywną rolę karmienia piersią w profilaktyce nowotworów. Do dziewcząt skierowano zaś zalecenie motywujące do szczepienia przeciwko wirusowi brodawczaka ludzkiego, znanemu jako czynnik ryzyka raka szyjki macicy; kolejny raz podkreślono konieczność szczepienia przeciwko wirusowemu zapaleniu wątroby typu B (IARC, 2015).

Podobnie jak w trzeciej wersji kodeksu, zalecenia dotyczące stylu życia w profilaktyce raka zakończono zaproszeniem do badań profilaktycznych w kierunku wczesnego wykrycia raka szyjki macicy, raka piersi i jelita grubego (IARC, 2015).

Popularyzacja zaleceń kodeksu jest ważnym elementem edukacji onkologicznej społeczeństw Unii Europejskiej, stanowiąc obecnie podstawę działań na rzecz ograniczania ryzyka zachorowania na choroby nowotworowe oraz zgonu $z$ ich powodu.

\section{Podstawy prewencji pierwotnej nowotworów w Polsce}

W Polsce działania na rzecz prewencji nowotworów przez wiele lat nie były sformalizowane. Elementy prewencji pierwotnej, jak na przykład zwiększenie aktywności fizycznej ludności, poprawa sposobu żywienia, ograniczenie palenia tytoniu i spożycia alkoholu oraz edukacja zdrowotna społeczeństwa pojawiły się w Narodowym programie zdrowia na lata 1996-2005 (Narodowy program zdrowia, 1996).

Ważną inicjatywą polskiego parlamentu było stworzenie we współpracy ze środowiskiem polskich onkologów i organizacjami zrzeszającymi chorych na nowotwory Narodowego programu zwalczania chorób nowotworowych, który 1 lipca 2005 roku został uchwalony przez Sejm. Program ten pozwolił podjąć zdecydowane działania, mające na celu zbudowanie strategii ograniczenia zachorowalności i umieralności z powodu nowotworów złośliwych w Polsce. W jego ramach powstało wiele programów profilaktycznych adresowanych do konkretnych grup odbiorców. Jednym z ważniejszych był Program prewencji pierwotnej nowotworów, którego zadaniem było zwiększenie świadomości społecznej i wiedzy o prewencji nowotworów w społeczeństwie polskim poprzez propagowanie zaleceń Europejskiego kodeksu walki z rakiem (Dz.U. 2005, nr 143 poz. 1200; Program prewencji pierwotnej, 2007).

Koordynatorem Programu prewencji pierwotnej nowotworów w skali kraju został Zakład Epidemiologii i Prewencji Nowotworów Centrum Onkologii - Instytutu im. Marii Skłodowskiej-Curie w Warszawie, który przygotował diagnozę wiedzy 
o nowotworach i profilaktyce w społeczeństwie polskim oraz zbudował sieć lokalnych realizatorów programu na poziomie województw. Aby realizować zadania w odniesieniu do potrzeb zdrowotnych różnych grup odbiorców w poszczególnych regionach kraju, przygotowano lokalne programy edukacyjne, oparte na diagnozie potrzeb oraz wytycznych koordynatora.

Ze względu na fakt, że program zakładał propagowanie zdrowego stylu życia i modyfikację niekorzystnych zachowań zdrowotnych w aspekcie profilaktyki raka, istotne było, aby poznały go grupy odbiorców najbardziej podatne na zmiany w zachowaniach zdrowotnych, czyli przede wszystkim dzieci i młodzież szkolna.

\section{Szkoła promująca zalecenia Europejskiego kodeksu walki $z$ rakiem w województwie świętokrzyskim}

Świętokrzyskie Centrum Onkologii, jako realizator Programu prewencji pierwotnej nowotworów od 2006 roku prowadziło edukację onkologiczną społeczeństwa. Powyższe działania skierowane były przede wszystkim do dzieci i młodzieży oraz nauczycieli i wychowawców. Jednocześnie prowadzonych było wiele działań adresowanych do środowisk medycznych oraz ogółu społeczeństwa poprzez konferencje, spotkania edukacyjne, akcje profilaktyczne oraz informacje medialne.

W 2010 roku realizatorzy programu z województwa małopolskiego i podkarpackiego wyszli z inicjatywą projektu Szkoły promującej zalecenia Europejskiego kodeksu walki z rakiem, w ramach, którego szkoły podejmowały różne formy aktywności mające na celu zapoznanie młodzieży z zaleceniami kodeksu. W latach 2010-2012 projekt zrealizowany był w blisko 3 tys. szkół. Projekt przedstawiony był na konferencji i spotkaniach roboczych wojewódzkich realizatorów programu i zaproponowany do realizacji w innych województwach. Najważniejszym celem projektu było zapoznanie jak największej grupy młodzieży z kodeksem walki z rakiem za pośrednictwem przeszkolonych nauczycieli, którzy prowadzili zajęcia w szkołach.

W województwie świętokrzyskim dotychczasowe działania wobec szkół przybrały formę projektu Szkoły promującej zalecenia Europejskiego kodeksu walki z rakiem w roku szkolnym 2013/2014. Celem głównym autorów projektu było kształtowanie postaw prozdrowotnych wśród uczniów szkół wszystkich typów w oparciu o zasady prewencji pierwotnej nowotworów zawarte w Europejskim kodeksie walki z rakiem.

Wśród celów szczegółowych zwrócono także uwagę na zwiększenie zakresu wiedzy uczniów na temat roli poszczególnych elementów stylu życia w profilaktyce nowotworów złośliwych poprzez zapoznanie z zaleceniami Europejskiego kodeksu walki z rakiem. Istotnym celem projektu było przede wszystkim zmotywowanie młodzieży do prowadzenia zdrowego stylu życia poprzez kształtowanie umiejętności dokonywania prozdrowotnych wyborów oraz modyfikacji negatywnych zachowań zdrowotnych, przy wsparciu przeszkolonych nauczycieli. Dzięki tym elementom: wiedzy, motywacji i umiejętnościom, dzieci i młodzież 
mają możliwość ukształtować postawę świadomej odpowiedzialności za zdrowie swoje i najbliższych.

Pod patronatem Świętokrzyskiego Kuratorium Oświaty zorganizowano konferencję, podczas której zaprezentowano projekt dyrektorom szkół i zaproszono ich do jego realizacji. Założono, że zajęcia w szkołach będą prowadzić przede wszystkim nauczyciele, którzy przeszkoleni zostaną podczas warsztatów edukacji onkologicznej, ale będą oni mogli korzystać ze wsparcia metodyka, specjalistów z zakresu profilaktyki i prewencji nowotworów, terapeutów uzależnień oraz dietetyka. Aby móc zwiększyć zakres wsparcia nauczycieli, do współpracy przy realizacji projektu, poza Kuratorium Oświaty, zaproszono Państwową Inspekcję Sanitarną oraz Świętokrzyskie Centrum Doskonalenia Nauczycieli.

W roku szkolnym 2013/2014 z zaproszenia na warsztaty edukacji onkologicznej skorzystało 137 nauczycieli ze 102 szkół województwa świętokrzyskiego. W kolejnym roku było to już 174 pedagogów ze 120 placówek. Poznali oni założenia projektu oraz zalecenia Europejskiego kodeksu walki z rakiem, ale uczyli się również pod kierunkiem psychologa, jak motywować uczniów do zmian w stylu życia. Z metodykiem zaś ze Świętokrzyskiego Centrum Doskonalenia Nauczycieli pedagodzy analizowali formy i techniki edukacji onkologicznej, które w największym stopniu będą aktywizować uczniów. Podczas warsztatów nauczyciele otrzymali konspekty zajęć i prezentacje multimedialne z możliwością elastycznego dostosowania ich treści do wieku i możliwości odbiorców, gdyż w projekcie zadeklarowały udział placówki różnego typu: szkoły podstawowe, gimnazja, szkoły ponadgimnazjalne oraz placówki ze specjalnymi potrzebami edukacyjnymi.

Nauczyciele i pedagodzy uczestniczący w projekcie uznali warsztaty za najlepszą formę przygotowania do prowadzenia zajęć z edukacji onkologicznej, ponieważ mieli możliwość nie tylko poszerzenia zakresu wiedzy, ale również umiejętności, dzięki dyskusji ze specjalistami z różnych dziedzin (psycholog, pedagog, metodyk, specjalista z zakresu zdrowia publicznego), którzy oferowali wsparcie w realizacji projektu nie tylko podczas, ale również po szkoleniu.

Aby umożliwić nauczycielom uczestnictwo w zajęciach warsztatowych bez konieczności dalekiego dojazdu, zaplanowano je w różnych powiatach województwa. Jesienią 2013 roku odbyły się one w Skarżysku-Kamiennej, Opatowie, Kielcach i Jędrzejowie. W kolejnej edycji projektu w roku szkolnym 2014/2015 warsztaty były zorganizowane w Ostrowcu Świętokrzyskim, Końskich, Busku-Zdroju, Sandomierzu i Kielcach, aby umożliwić uczestniczenie w tej formie szkolenia nauczycielom z kolejnych powiatów. Dzięki temu więcej osób mogło skorzystać z powyższej formy przygotowania do realizacji projektu i zyskało większe kompetencje do edukacji onkologicznej uczniów.

Warsztaty sprzyjały również wymianie doświadczeń pomiędzy nauczycielami, którzy prowadzili wcześniej zajęcia z zakresu prewencji nowotworów oraz przekazywaniu tzw. „dobrych praktyk”, czyli sprawdzonych propozycji zajęć z młodzieżą.

Każdy nauczyciel po przeszkoleniu miał przekazać młodzieży w swojej placówce nie tylko wiedzę, ale i umiejętności, dlatego konspekty zajęć zawierały 
wiele elementów aktywizujących uczniów, pytań skłaniających do dyskusji oraz materiałów do analizy własnego stylu życia z receptą na zdrowe życie, którą wypisuje sobie sam uczeń. Nauczyciele mieli możliwość przeprowadzenia w szkole zajęć warsztatowych dla uczniów o tematyce antytytoniowej pt. „Dziękuję - nie palę" oraz prozdrowotnej pt. „Zdrowo żyję - ćwiczę, biegam i nie tyję”, spotkań ze specjalistami z zakresu prewencji nowotworów, wsparcia w organizacji badań, między innymi pomiaru tlenku węgla w wydychanym powietrzu dla biernych i czynnych palaczy, pomiarów tkanki tłuszczowej itp.

Poza konspektami zajęć i prezentacjami multimedialnymi nauczyciele mieli możliwość otrzymania dla uczniów egzemplarzy kodeksu, przedstawionego w formie komiksowej w dwóch wersjach - dla młodszych i starszych uczniów (materiał przygotowany przez koordynatora programu). Z opinii nauczycieli wynika, że były to bardzo pomocne w realizacji zajęć materiały edukacyjne, jednak nie wszyscy mieli możliwość z nich skorzystać (ograniczona w liczba egzemplarzy przekazanych od koordynatora programu z Centrum Onkologii - Instytutu w Warszawie).

Po zakończeniu zajęć w ramach projektu w placówce, szkolny koordynator składał sprawozdanie i otrzymywał dla szkoły certyfikat Szkoły promującej zalecenia Europejskiego kodeksu walki z rakiem za dany rok szkolny.

\section{Analiza realizacji projektu Szkoła promująca zalecenia Europejskiego kodeksu walki z rakiem w roku szkolnym 2013/2014 i 2014/2015}

Efektem prowadzonych w roku szkolnym 2013/2014 zajęć było objęcie projektem 146 szkół z terenu województwa świętokrzyskiego, natomiast w kolejnym roku szkolnym uczestniczyły w nim już 234 placówki, co świadczy o dużym zainteresowaniu projektem i potrzebie realizacji w szkołach zajęć z zakresu edukacji onkologicznej. Zalecenia Europejskiego kodeksu walki z rakiem poznało w roku szkolnym 2013/2014 aż 20457 uczniów świętokrzyskich szkół z 66 szkół podstawowych (6333 uczniów), 48 gimnazjów (8045 uczniów) oraz 32 szkół ponadgimnazjalnych (6079 uczniów). W roku szkolnym 2014/2015 w projekcie uczestniczyło nieco mniej, bo18 810 uczniów, ze 104 szkół podstawowych (6555 uczniów), 82 gimnazjów (8352 uczniów) i 48 szkół ponadgimnazjalnych (3903 uczniów).

Zarówno podczas pierwszej, jak i drugiej edycji projektu w świętokrzyskich szkołach, szkolni koordynatorzy zapoznali z kodeksem walki z rakiem innych nauczycieli podczas Rady Pedagogicznej. W roku szkolnym 2013/2014 odbyło się 20 spotkań, natomiast w kolejnym roku już dwukrotnie więcej (40 spotkań - 1153 nauczycieli), co wpłynęło korzystnie na zaangażowanie innych nauczycieli w realizację projektu w szkole. Dzięki takiemu zaangażowaniu, wielu nauczycieli podjęło się prowadzenia zajęć nie tylko we własnej placówce, ale także w innych szkołach, zwiększając zakres projektu.

Podczas obu edycji nauczyciele prowadzili zajęcia w oparciu o konspekty i prezentacje multimedialne podczas 45-minutowych zajęć, bądź dzieląc je na 
kilka godzin lekcyjnych. Po pierwszej edycji na bazie analizy ankiet ewaluacyjnych skrócono prezentację, aby dostosować ją do potrzeb nauczycieli.

W sprawozdaniach nauczyciele - koordynatorzy projektu podawali często własne autorskie pomysły na przekazanie wiedzy o kodeksie, między innymi we współpracy z innymi nauczycielami, włączali tematykę prewencji nowotworów do zajęć w ramach różnych przedmiotów, np. na lekcji języka niemieckiego omawiano zalecenia kodeksu, na lekcji chemii analizowano skład dymu papierosowego, itd. Wielu nauczycieli wykorzystywało też obecność edukacji zdrowotnej w podstawie programowej do wyszukiwania treści związanych z Kodeksem i włączania ich do programu nauczania. W jednej ze szkół podstawowych wprowadzono kampanię tzw. „Zdrowy kwartał”, podczas której każdego dnia tygodnia uczniowie mieli zaakcentowane inne zalecenie kodeksu, między innymi dzień bez chipsów, dzień z warzywami i owocami, dzień z zajęciami ruchowymi na przerwie. Uczniowie sami motywowali swoich kolegów do przestrzegania zasad panujących w szkole.

Różnorodność działań podejmowanych w szkołach widoczna była w wielu sprawozdaniach z realizacji projektu. Przy okazji tzw. świąt zdrowia, jak np. Światowy Dzień Walki z Rakiem, Światowy Dzień Rzucania Palenia, w wielu szkołach odbywały się spotkania z terapeutami uzależnień (nt. szkodliwości palenia), dietetykami i innymi specjalistami, co pozwoliło na eksponowanie wybranych zaleceń Europejskiego kodeksu walki z rakiem, takich jak: żywienie, aktywność ruchowa, używki.

W obu edycjach projektu jego realizacji w szkołach towarzyszyło podejmowanie różnych form aktywności fizycznej, dostępnych dla całej społeczności szkolnej, np. rajdy piesze lub rowerowe, długie przerwy z ćwiczeniami prowadzonymi przez uczniów lub nauczycieli wf., czy „roztańczona przerwa” organizowana przez jedno z gimnazjów. Są to przykłady kształtowania wśród młodzieży umiejętności prowadzenia aktywnego życia, traktowania turystyki pieszej czy rowerowej jako formy aktywnego wypoczynku w dni wolne od zajęć lekcyjnych. W wielu z powyższych działań uczestniczyli nie tylko uczniowie, ale również rodzice i cała społeczność lokalna.

Bardzo istotnym efektem działań edukacyjnych prowadzonych w szkołach podczas obu edycji było zapoznanie z zaleceniami Europejskiego kodeksu walki z rakiem 4843 rodziców uczniów (2013/2014 - 1689 osób, 2014/2015 - 3154 osoby) podczas wywiadówek szkolnych. Powyższe działania są cenne ze względu na możliwość dotarcia $z$ wiedzą o profilaktyce nowotworów do grupy odbiorców czynnych zawodowo, którzy często z racji tzw. „braku czasu” nie uczestniczą w akcjach popularyzacyjnych, a jednocześnie motywują do zapoczątkowania pozytywnych zmian w stylu życia nie tylko własnych dzieci, ale całej rodziny.

Wiele szkół prowadziło akcję medialną w lokalnej prasie, na stronach internetowych oraz w samej placówce poprzez publikację kodeksu na gazetkach szkolnych i plakatach, co wpłynęło także korzystnie na zwiększenie świadomości społecznej w otoczeniu placówki. 


\section{Ocena projektu przez uczestniczących w nim nauczycieli w roku szkolnym 2013/2014}

Zdecydowana większość - 86\% ankietowanych nauczycieli oceniło projekt Szkoły promującej zalecenia Europejskiego kodeksu walki z rakiem bardzo wysoko, podkreślając, że dobrze przybliża zagadnienie prewencji nowotworów. Zdaniem respondentów projekt ma odpowiednio dobrane i atrakcyjne dla uczniów materiały dostosowane do różnych kategorii wiekowych, ciekawe warsztaty i pomoce dydaktyczne dla nauczycieli. Istotne zdaniem ankietowanych jest też wsparcie koordynatora projektu na poziomie wojewódzkim.

Według szkolnych koordynatorów projekt podsuwa pomysły na formy realizacji szkolnego programu wychowawczego w zakresie promocji zdrowia.

Około 14\% respondentów oceniło projekt na „czwórkę", jako argument podając między innymi:

- brak profesjonalnych warsztatów dla uczniów z pracownikiem onkologii -wopiniijednego nauczycielazgimnazjumijednego ze szkoły podstawowej;

- mało atrakcyjny komiks dla szkoły ponadgimnazjalnej;

- konieczność uatrakcyjnienia programu i zaangażowania rodziców.

Kilku nauczycieli zwróciło uwagę na brak pełnej dostępności komiksów, które są dobrym materiałem edukacyjnym.

W opiniach ankietowanych nauczycieli pojawiały się propozycje urozmaicenia projektu o nowe materiały dla uczniów, między innymi filmu i pokazu, gry edukacyjnej propagującej kodeks, krzyżówki tematycznej, co zostanie uwzględnione w kolejnych edycjach.

\section{Podsumowanie}

Analiza wyników ankiety pozwala stwierdzić, że projekt oceniony został bardzo dobrze, a jego realizatorzy zapytani o możliwość uczestniczenia w jego kolejnej edycji zgodnie potwierdzili, że chętnie wezmą w nim udział ponownie ze względu na wagę tematu oraz konieczność zwiększania świadomości społecznej w zakresie prewencji nowotworów zarówno wśród dzieci, jak i rodziców. Nauczyciele podkreślali, że zagadnienia dotyczące profilaktyki chorób nowotworowych należy na stałe włączyć do programu nauczania w szkole.

Prewencja pierwotna nowotworów jest istotnym zadaniem społeczeństw na całym świecie ze względu na rosnącą wciąż liczbę zachorowań na nowotwory złośliwe. Wzrastająca liczba dzieci i młodzieży z problemem nadwagi i otyłości, siedzący tryb życia i niewłaściwa dieta powodują wzrost ryzyka nowotworów u coraz młodszych osób (Young, 2011). Równie istotny jest wzrost liczby palących dziewcząt, który obserwuje się na świecie, powodujący już dziś wzrost umieralności kobiet z powodu raka płuca (Zatoński, 2007). 
Powyższe dane wskazują na konieczność prowadzenia edukacji onkologicznej wśród dzieci i młodzieży szkolnej w oparciu o sprawdzone i skuteczne metody. W tym celu potrzebna jest wymiana doświadczeń pomiędzy instytucjami i organizacjami prowadzącymi edukację w szkołach, która powinna zaowocować powstawaniem projektów opartych na dobrych praktykach, angażujących młodzież w edukację rówieśniczą, gdzie poszczególne elementy edukacyjne będą się wzajemnie uzupełniać i wzmacniać, a materiały edukacyjne przygotowane we współpracy z młodzieżą będą atrakcyjne i łatwo dostępne dla odbiorcy.

\section{Wnioski}

1. Z analizy projektu realizowanego w latach 2013-2015 w województwie świętokrzyskim wynika, że strategia edukacji onkologicznej w szkołach, oparta na aktywnym udziale nauczycieli współpracujących ze specjalistami z zakresu prewencji nowotworów stanowi właściwy kierunek dla dalszych prac. Pozwala ona zwiększać zakres działań edukacyjnych wobec dzieci i młodzieży szkolnej niezależnie od dostępności środków finansowych ułatwiających dotarcie profesjonalistów z zakresu onkologii do szkół.

2. Zarówno bardzo wysoka ocena jak i pozytywne opinie nauczycieli realizujących projekt Szkoły promującej zalecenia Europejskiego kodeksu walki z rakiem w województwie świętokrzyskim wskazują, że chcą oni realizować powyższą formę edukacji onkologicznej w swoich placówkach i czują się przygotowani do prowadzenia zajęć, dzięki uczestnictwu w warsztatach. O zainteresowaniu proponowanymi formami zajęć w szkołach świadczy też rosnąca liczba placówek, które przystąpiły do projektu w kolejnym roku szkolnym. Aktualność treści i społeczne znaczenie projektu zachęca nauczycieli do jego realizacji.

3. Podczas warsztatów i konferencji tematycznych dotyczących wybranych nowotworów czy zmian w zaleceniach z zakresu prewencji raka, nauczyciele aktualizują i poszerzają zakres swojej wiedzy, co zwiększa ich kompetencje do samodzielnego prowadzenia edukacji onkologicznej w szkole. W związku z powyższym podczas kontynuacji projektu należy uwzględnić systematyczną edukację pedagogów poprzez konferencje i seminaria oraz spotkania warsztatowe, zarówno dla nauczycieli rozpoczynających realizację projektu, jak i dla dotychczasowych szkolnych koordynatorów.

4. Ważnym elementem strategii edukacyjnej zdaniem nauczycieli są materiały - konspekty i prezentacje, modyfikowane i przygotowywane przez wojewódzkiego realizatora programu we współpracy ze Świętokrzyskim Centrum Doskonalenia Nauczycieli. W ich opinii powyższe materiały pozwalają aktywizować ucznia podczas zajęć, skłaniać do zastanowienia i samodzielnej diagnozy własnych zachowań zdrowotnych w odniesieniu do prewencji nowotworów oraz otwierają nauczycielom drogę do dalszego rozszerzania zakresu edukacji onkologicznej w zależności od zdiagnozowanych potrzeb podopiecznych. Nowe materiały powinny być 
przygotowane we współpracy z metodykami oraz nauczycielami w oparciu o dotychczasowe doświadczenia.

5. Ankietowani nauczyciele podkreślali także znaczenie zaangażowania specjalistów z różnych dziedzin do jego realizacji, między innymi dietetyka, psychologa, specjalistów z zakresu prewencji nowotworów, metodyka oraz terapeutów uzależnień dla kompleksowego wsparcia szkolnego koordynatora i urozmaicenia programu w placówce, co wskazuje na potrzebę nawiązywania współpracy z tymi profesjonalistami w lokalnych społecznościach.

6. W sprawozdaniach szkół realizujących projekt często pojawiały się działania promujące zalecenia kodeksu w innych placówkach. Obserwując zaangażowanie nauczycieli i wychowawców oraz młodzieży z wielu szkół na szczeblu gimnazjalnym i ponadgimnazjalnym w promowanie edukacji onkologicznej w sąsiednich szkołach nasuwa się wniosek, że istotnym elementem projektu w kolejnych latach powinno być stymulowanie współpracy szkół realizujących projekt w danym powiecie przy organizacji działań związanych z edukacją onkologiczną w środowisku lokalnym.

7. Młodzież aktywnie włączająca się do działań edukacyjnych poprzez uczestnictwo w akcjach społecznych z zakresu prewencji nowotworów oraz udział w konkursach aktywizujących twórczo (między innymi dramy, spektakle profilaktyczne) powinna stale pogłębiać swą wiedzę z zakresu prewencji nowotworów, aby móc skutecznie prowadzić edukację rówieśniczą pod kierunkiem przygotowanego nauczyciela. W projekcie na kolejne lata należy uwzględnić konieczność organizacji warsztatów i seminariów dla wybranych grup młodzieżowych liderów zdrowia.

8. Doświadczenia nauczycieli realizujących projekt w latach 2013-2015 są ważnym elementem dla budowania strategii edukacyjnej na kolejne lata. W oparciu o propozycje działań wyrażone przez szkolnych koordynatorów w ankietach należy dążyć do przygotowania nowych atrakcyjnych materiałów dla młodzieży oraz promować, jako przykłady dobrych praktyk, realizowane przez nich nowatorskie działania, opisywane w sprawozdaniach.

\section{Bibliografia}

Jarosz M., 2008, Nowotwory złośliwe. Jak zmniejszyć ryzyko zachorowania, PZWL, Warszawa, s. 20. Program prewencji pierwotnej w ramach Narodowego programu zwalczania chorób nowotworowych,

„Eskulap Świętokrzyski” 2007, nr 1, s. 11-12.

Światowa deklaracja walki z rakiem 2006, Centrum Onkologii - Instytut, Warszawa, s. 7-15.

Young I., 2011, Jak wspierać rozwój i zdrowie młodzieży, Ośrodek Rozwoju Edukacji, Warszawa.

Zatoński W., Profesor Witold Zatoński radzi, jak rzucić palenie, Warszawa, Fundacja Promocja Zdrowia, 2007, s. 10.

Zatoński W. (red.), 2009, Europejski kodeks walki z rakiem, Centrum Onkologii - Instytut im. Marii Skłodowskiej-Curie, Warszawa. 


\section{Akty prawne}

Ustawa z dnia 1 lipca 2005 r o ustanowieniu programu wieloletniego Narodowy Program Zwalczania Chorób Nowotworowych. Dz.U. 2005 nr 143 poz. 1200.

\section{Żródła internetowe}

Międzynarodowa Agencja Badań nad Rakiem [IARC], 2015, Europejski kodeks walki z rakiem. 12 sposobów na zmniejszenie ryzyka zachorowania na raka. Pozyskano ze strony: http://cancer-code-europe.iarc.fr/index.php/en/ dn. 6 sierpnia 2015

Ministerstwo Zdrowia i Opieki Społecznej [MZiOS] 1996, Narodowy Program Zdrowia na lata 19962005. Pozyskano ze strony: http://www2.mz.gov.pl/wwwmz/index?mr= m111111\&ms $=\& m-$ $\mathrm{l}=\mathrm{pl} \& \mathrm{mi}=\& \mathrm{mx}=0 \& \mathrm{mt}=\& \mathrm{my}=\& \mathrm{ma}=0237 \mathrm{dn} .6$ sierpnia 2015

Paryska karta walki z rakiem, 2000. Pozyskano ze strony: http://www.puo.pl/program-walki-z-rakiem/ archiwum/paryska-karta-walki-z-rakiem z dn. 6 sierpnia 2015, godz. 13.00 